\title{
DIREITOS HUMANOS E INCLUSÃO NO ENSINO SUPERIOR: UM ESTUDO DE CASO ACERCA DAS REPRESENTAÇÕES DOCENTES E DISCENTES COM DEFICIÊNCIA, SOB O ESCOPO DA DIVERSIDADE E ALTERIDADE
}

Human rights and inclusion in higher education: $A$ case study about the representations of teachers and students with disabilities, under the scope of diversity and otherness

Antonio Carlos da Silva Universidade Católica do Salvador (PPGPSC/UCSAL)

Matheus Martins de Oliveira Universidade Católica do Salvador (UCSal)

Informações do artigo

Recebido em 16/03/2021

Aceito em 01/05/2021

doi>: https://doi.org/10.25247/2447-861X.2021.n252.p103-133

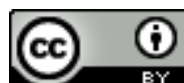

Esta obra está licenciada com uma Licença Creative Commons Atribuição 4.0 Internacional.

\section{Como ser citado (modelo ABNT)}

SILVA, Antonio Carlos da; OLIVEIRA, Matheus Martins de. Direitos humanos e inclusão no ensino superior: um estudo de caso acerca das representações docentes e discentes com deficiência, sob o escopo da diversidade e alteridade. Cadernos do CEAS: Revista Crítica de Humanidades. Salvador/Recife, v. 46, n. 252, p. 103-133, jan./abr. 2021. DOI: https://doi.org/10.25247/2447-

861X.2021.n252.p103-133

\section{Resumo}

O presente artigo pretende descrever e analisar as representações conceituais sobre Direitos Humanos e Inclusão social, tomando como comunidade alvo docentes e discentes da Universidade Católica do Salvador, pertencente ao biênio 2018/9. Verificar-se-á através de metodologia qualitativa os quatro eixos que compõem o objeto-tema (direitos humanos, inclusão social, diversidade e alteridade) descrevendo conteúdos a partir da experiência acadêmica e social permeadas na formação continuada (ensino, pesquisa, extensão) durante curso superior. Uso de levantamento bibliográfico e legislativo, com destaque às diretrizes do Plano Nacional e Estadual de Educação para Direitos Humanos, instituições do sistema de justiça nacional e estadual, planejamento e matrizes curriculares institucionais (Justiça e Educação Superior), também houve procedimento de coleta de dados junto aos sujeitos envolvidos na comunidade acadêmica, quais sejam, gestores/as, corpo docente e discente em suas múltiplas áreas e modalidades, buscando retratar e usar a abordagem de cartografia social para descrever e analisar as representações atinentes ao eixo da investigação.

Palavras-Chave: Direitos Humanos. Inclusão. Diversidade. Educação.

\section{Abstract}

This article aims to describe and analyze the conceptual representations on Human Rights and Social Inclusion, taking as a target community teachers and students from the Catholic University of Salvador, belonging to the 2018/9 biennium. The four axes that make up the theme-object (human rights, social inclusion, diversity and alterity) will be verified through qualitative methodology, describing contents based on academic and social experience permeated in continuing education (teaching, research, extension) during higher education. Use of bibliographic and legislative survey, with emphasis on the guidelines of the National and State Plan of Education for Human Rights, institutions of the national and state justice system, planning and institutional curricular matrices (Justice and Higher Education), there was also a procedure for data collection with the subjects involved in the academic community, namely, managers, faculty and students in its multiple areas and modalities, seeking to portray and use the social cartography approach to describe and analyze the representations related to the research axis.

Keywords: Human Rights. Inclusion. Diversity. Education. 


\section{Introdução e ponto de partida comum}

Metodologia abordada em tempos de violações

O acesso à educação de pessoas com deficiência se torna relevante em razão das transformações ocorridas a partir da constituição desse direito social fundamental, por meio de sua concretização nas políticas públicas educacionais inclusivas e $\mathrm{AEE}^{1}$, sob a ótica dos direitos humanos e da efetivação do princípio da igualdade, o que pretende demonstrar que, além de tratar-se de um direito constitucional autoaplicável, é também um direito indisponível, razão pela qual a obrigação de implantá-lo recai sobre os entes públicos, em suas diferentes acepções e hierarquias, e por toda a sociedade em si mesma.

Nesse contexto, o objetivo (geral) do presente trabalho é analisar a função da educação especial desenhada na política educacional (inter)nacional para estabelecer uma correlação no conteúdo das diretrizes do Plano Nacional e Estadual de Educação para os Direitos Humanos, para evidenciar as propostas ali construídas e a forma de atendimento do público-alvo da educação especial. Com efeito, vamos mapear, descrever e analisaras representações de Direitos Humanos e Inclusão Social tomando como comunidade alvo os docentes e discentes que sejam pessoas com deficiência na Universidade Católica do Salvador - UCSal, pertencente ao biênio 2018 a 2019.

Assim, considerando os objetivos (específicos), temos: a) perceber se a educação superior e o acesso à justiça e à cidadania estão pautados e referendados como sujeitos de Direitos, que precisam de uma resposta específica e diferenciada desde a oportunidade, aliada à concepção da discriminação positiva junto ao ambiente acadêmico; b) aprofundar as representações e as percepções de conceitos e práticas sociais e se as mesmas são fomentadas e orientadas para a formação integral do sujeito - em sua acepção ética e histórica; e c) notar se existe vivência e convivência de/na/para diversidade e para/pelos Direitos Humanos na UCSal, com destaque às deficiências, para inferir se são parte do processo formativo e inclusivo aliada à práxis do direito positivado posto e a efetiva colocação na formação continuada de ensino, pesquisa e extensão na Universidade.

\footnotetext{
1 AEE: Atendimento Educacional Especializado, que organiza atividades, recursos pedagógicos e de acessibilidade, de forma complementar ou suplementar à escolarização dos estudantes com deficiência.
} 
A partir do objetivo geral e dos específicos já bem delimitados, sugere-se como problema de pesquisa a indagação formulada na pergunta que segue: existe diversidade de/na/para inclusão e direitos humanos das pessoas com deficiência, na Universidade Católica do Salvador - UCSal pertencentes ao biênio 2018-2019?

Nessa acepção, a escolha do ambiente acadêmico, de ensino superior atribui-se ao fato de a Universidade - nas modalidades graduação e pós-graduação stricto sensu, representar componente basilar da formação avançada no exercício de cidadania e das dimensões dos Direitos Humanos, a partir das agendas e práticas de inclusão social que promovem a chamada Alteridade, onde a delimitação indicada para a comunidade docente/discente da UCSal, como instituição-chave para a pesquisa, não se deve meramente ao fato de estar integrado como discente - compreendido na mais pura acepção do lugar de fala (RIBEIRO, 2019), mas sim, atribui-se que, nesse estágio formativo, a Instituição assinala o dever ético na missão de contribuir para a transformação da sociedade, valorizando a vertente comunitária e educativa de profissionais cidadãos/ãs, críticos/as e comprometidos/as com a busca de soluções para os problemas(BAUMAN, 2001).

Assim, a importância social deste estudo está firmada para a garantia dos princípios constitucionais frente aos cidadãos - com e sem deficiência, de forma que essa parcela expressiva, ainda que de maneira incipiente (IBGE, 2012) possa ser integrada na sociedade por meio do acesso às Instituições de Ensino Superior - IES, bem como da justiça e das assinalações históricas desta parcela da sociedade. Justificando, pois, que, em contexto de graves violações de direitos e forte instabilidade macro política, de crises contínuas, que afetam as estruturas e categorias econômicas/sociais, partindo de pressupostos teóricos que reforçam a vinculação interdisciplinar, sobre complexidade e crítica/ética em tempos alteres, envolvendo áreas do conhecimento e análises sobre realidade onde as dimensões não são vazias ou tautológicas, cujas experiências, em nível superior, cumpram-se como colaborativa na formação promovente de diversidade e pensamento crítico para se atingir a cidadania.

Diante de tudo isso, é inerente a visão não estigmatizada (GOFFMAN, 1988) da temática, pautada na universalidade da igualdade de acesso como princípio, a partir das leituras abordadas para uma educação integral e inclusiva, onde a escolha da metodologia foi baseada no levantamento bibliográfico e exploratório através das plataformas de busca de repositórios com teses, artigos e dissertações, bem como a utilização, análise e estudo de pactos internacionais, legislações, decretos, documentos institucionais orientadores, que 
concomitante visam alcançar esse ideário de justiça (HÖFFE, 2003; LYRA FILHO, 2003), frente ao sistema capitalista.

Por fim, a abordagem utilizada é a qualitativa, buscando-se analisar o fenômeno social estudado (RAUPP; BEUREN, 2013), explicando o porquê dessa dinâmica social e o que deverá ser feito com relação a esse fenômeno, uma vez evidenciados através de interpretações de aspectos da realidade (GERHARDT; SILVEIRA, 2009) como violação dos Direitos Humanos, ruptura dos contextos familiares, entre outras questões subjetivas que serão abordadas ao final deste trabalho. Trazendo, assim, vertentes historiográficas do Estado da Arte (ROMANOWSKI; ENS, 2006, p. 37-50) sobre o assunto, valorizando o pensamento clássico e contemporâneo, executando procedimento de coleta de dados junto aos sujeitos envolvidos - sejam gestores/as, corpo docente e/ou discentes em suas múltiplas áreas, através de elaboração de entrevistas semiestruturadas- virtuais e presenciais, realizadas com igual paridade entre sexo/gêneros, raça/etnia/cor e afins de Pessoas com Deficiência (PcD's) e toda análise de conteúdo precedente à coleta empírica.

Houve uma parte descritiva/informativa primada pela confidencialidade e sigilo dos dados coletados, devidamente, com procedimento do Termo de Consentimento Livre e Esclarecido (TCLE), incluindo, paritariamente, os componentes que integrem os critérios abordados do corpo (do) discente, orientados pelas seguintes sessões de perguntas:(I) dados gerais; formação, disciplinas, marcos sobre centro do estudo; (II) o que se entende como representações de direitos humanos e inclusão vivencial na UCSal. Fazendo-nos compreender e, principalmente, destacar o direcionamento das políticas públicas em torno da universalidade e especificidade dos direitos educacionais-sociais, exprimindo-se através desses status de promoção da igualdade material tão desejada, onde se conclui que as específicas e diferenciadas oportunidades de ingresso nos cursos superiores se mostram insuficientes e intimamente ligadas à permanência destes nas Instituições de Ensino Superior, mediante ações educacionais concretamente integradas.

Histórico a que se refere pessoas com deficiência

De início, faz-se preciso conceituar o grupo social e os sujeitos englobados nessa proposta metodológica que resultou no presente artigo científico. É sabido que o conceito de deficiência mudou, e que o termo "portador" de necessidades especiais era caracterizado de modo mais amplo, aderindo outros segmentos da sociedade, como, por exemplo, gestantes e afins, onde, nesse prisma, fica evidente que nem sempre se demonstrava a deficiência como 
integrante ao ser, mas sim como algo acessório/dispensável, que um dia este seria liberto pela avançar da cura medicinal.

Assim, advindo da evolução histórica inerente às nomenclaturas ora trazidas pela Organização Mundial da Saúde (OMS), partimos do já conhecido CIDID² que, virtuosamente, se transformou no $\mathrm{CIF}^{3}$ já com avanços consideráveis (CHATEAU, 2018, p. 2-3), onde hoje, e felizmente que seja assim, temos como compreensão majoritária o conceito de deficiência se dá através de avaliação biopsicossocial, ou seja, biológica, psíquica e também social (DEMARCO, 2014). Este modelo social de deficiência, apontando em contraposição ao modelo biomédico, transfere para a sociedade a responsabilidade de realizar adaptações necessárias, uma vez que é de sua coparticipação nesse processo, ou, do contrário, legitimaria a opressão dessas pessoas:

A perspectiva social da deficiência colabora com a ideia de promoção dos direitos e inclusão da pessoa com deficiência, pois devolve à sociedade o seu papel e responsabilidade ao excluir esse sujeito. A partir dessa concepção, é possível verificar a importância de se desenvolver instrumentos facilitadores do desenvolvimento e autonomia da pessoa com deficiência [...] (D'ALBUQUERQUE, 2017, p. 32).

Para tanto, faz-se necessário usar as nomenclaturas corretas e, no tocante a esse segmento, o termo atual a ser utilizado é Pessoa com Deficiência - PcD, pois, ao ser adotado em predileção aos anteriores, denota preponderantemente o poder pessoal de assumir/controlar suas escolhas, bem como o de se colocar conforme seus talentos ou até debilidades/habilidades já inerentes a esses sujeitos, dotados sim de capacidade.

Nesse prisma, em nível mundial foi adotado um viés controverso para essa expressão em todos os idiomas (SASSAKI, 2003, p. 14-15) e que concordamos estar mais adequado, ao partir dos próprios sujeitos de direitos envolvidos, chega-se à ideia, quase de modo consensual, a despeito da terminologia, que, inclusive, se tornou mais ressaltada, conforme o Conselho Nacional dos Direitos da Pessoa com Deficiência - CONADE4 .

\footnotetext{
${ }^{2}$ CIDID: Classificação das Deficiências, Incapacidades e Desvantagens (Handicaps). ORGANIZAÇÃO MUNDIAL DA SAÚDE [OMS]. CID-IX Revisão da classificação internacional de doenças. Porto Alegre: Sagra, 1976.

3 CIF: Classificação Internacional de Funcionalidade, Incapacidade e Saúde. ORGANIZAÇÃO MUNDIAL DA SAÚDE [OMS]. Classificação Internacional das Deficiências, Incapacidades e Desvantagens (Handicaps): manual de classificação das consequências das doenças. Lisboa: Secretaria Nacional de Reabilitação, 1989. 4 SECRETARIA ESPECIAL DOS DIREITOS DA PESSOA COM DEFICIÊNCIA. Conselho Nacional dos Direitos da Pessoa com Deficiência (CONADE). Disponivel em http://www.pessoacomdeficiencia.gov.br/app/conade Acesso em 15 de abril 2021.
} 
Compreensível estabelecer que, somente em 1972, no país do Reino Unido, a partir do sociólogo Paul Hunt (o qual tinha deficiência física), postulou-se um primeiro olhar acerca da deficiência como aspecto social, que se caracterizava por associar os valores simbólicos, os sinais corporais e os estigmas neles contidos. Assim, um de seus escritos mais famosos, ainda em 1972, para o jornal inglês The Guardian 5 teve um impacto gigantesco, que propiciou a primeira organização política sobre deficiência, onde, diferentemente das demais, essa tinha conotação de enfretamento social e não assistencialista, atendendo os conceitos atuais já difundidos pelo lema "nada sobre nós, sem nós", a qual era gerenciada pelas próprias PcD's, através das ONGs representativas, servindo de fonte consultiva de direitos (DINIZ, 2007, p. 13-14).

Historicamente, esses indivíduos atravessam certo grau de exclusão e de vida à margem da sociedade que os permeia, onde, segundo Flávia Piovesan ${ }^{6}$, de maneira sintética, todo esse período pode se classificar em quatro etapas: I.Da intolerância, onde a deficiência era vista como uma maldição, castigo relativo a alguma impureza ou pecado divino; II. Da invisibilidade, onde simplesmente se ignorava o fato de que esse grupo existia e muito menos se reconhecia seus direitos; III. A assistencialista, onde se apregoava apenas o modelo médico, fazendo com que a deficiência fosse vista exclusivamente sob a ótica da cura de sua enfermidade; IV. E a humanista - e atual, a qual é orientada frente aos novos paradigmas e sob o jugo dos Direitos Humanos, que visam a uma inclusão no trato social, a partir do indivíduo que reconhece sua deficiência como interação com o meio e encontra respaldo no romper de suas barreiras (sejam elas culturais, físicas ou sociais), para, assim, um dia superálas (LAZARI; GARCIA, 2017).

Nesse mesmo sentido, é possível notar que a própria legislação acompanhou essa compreensão geracional e, assim, "evoluiu" junto com o próprio Direitos Humanos, com efeito de conseguir ter esculpido na letra da lei os conceitos e a quem se destina essas políticas públicas de "proteção" e, mais apropriadamente, de oportunizações específicas. De modo que a responsabilização inerente aos seus descumpridores (incluindo o Estado), ao longo desse processo de inclusão educacional, dos institutos jurídicos basilares que norteiam

5 Original: HUNT, Paul (Ed.). Stigma: The experience of disability. London: Chapman, 1966.

${ }^{6}$ PIOVESAN, Flávia. Direitos humanos e o direito constitucional internacional. São Paulo: Saraiva, 2008. 
a temática, fazendo necessário mencionar a Convenção Internacional sobre os Direitos das Pessoas com Deficiência - CDPD. Isso porque confirmam-se atualidade e abrangência, culminando mais apropriadamente na definição atual, logrando êxito de maneira positivada, o conceito de deficiência como compreendido nos dias de hoje, através da concepção social7 já explicada, logo em seu Art. 10:

O propósito da presente Convenção é o de promover, proteger e assegurar o desfrute pleno e equitativo de todos os direitos humanos e liberdades fundamentais por parte de todas as pessoas com deficiência e promover o respeito pela sua inerente dignidade.

Pessoas com deficiência são aquelas que têm impedimentos de natureza física, intelectual ou sensorial, os quais, em interação com diversas barreiras, podem obstruir sua participação plena e efetiva na sociedade com as demais pessoas.

Mediante seu protocolo facultativo, assinado em New York em 2007, a CDPD obteve, por meio de sua promulgação ${ }^{8}$, status de emenda constitucional, com base na Constituição Federal de 1988, art. $5^{\circ}, \sqrt{3}{ }^{\circ 9}$, atendendo aos critérios de supra legalidade no bloco constitucional, do qual o Brasil, a partir de seu plano interno, regulamentou e repensou toda política de inclusão e legislação que não estivesse em conformidade, por força da hierarquia das normas proposta por Hans Kelsen ${ }^{10}$.

Bem verdade que já não vínhamos tão mal assim, pois, de algum modo, nossa Constituição de 1988 - CF/88 é muito avançada, já no que diz respeito à matéria dos Direitos Humanos, alicerçada nos fundamentos democráticos para realização da dignidade da pessoa humana como princípio basilar através dos seus direitos e garantias fundamentais (PIOVESAN, 2013).

Com efeito, outro instituto jurídico o qual é imprescindível mencionar, a Lei no 13.146/2015, que disciplinou no ordenamento pátrio o tratado ora mencionado e instituiu a chamada Lei Brasileira de Inclusão - LBI(ou mais conhecida, também, como Estatuto da Pessoa com Deficiência - EPD), assimilandoas inovações trazidas pela Convenção, onde, no

7DINIZ, Debora. O que é deficiência? (Coleção Primeiros Passos; 324). São Paulo: Brasiliense, 2007.

${ }^{8}$ Decreto no 6949/2009: Promulga a Convenção Internacional sobre os Direitos das Pessoas com Deficiência e seu Protocolo Facultativo, assinados em Nova York, em 30 de março de 2007.

${ }^{9} \mathrm{CF}$ 1988, art. $5^{\circ}, \sqrt{ } 3^{\circ}$ "Os tratados e convenções internacionais sobre direitos humanos que forem aprovados, em cada Casa do Congresso Nacional, em dois turnos, por três quintos dos votos dos respectivos membros, serão equivalentes às emendas constitucionais" Incluído pela Emenda Constitucional n 45, de 2004.

${ }^{10}$ KELSEN, Hans. Teoria Pura do Direito. 6a ed. São Paulo: Martins Fontes, 1998. 
que diz respeito à definição de pessoa com deficiência, o Art. $2^{\circ}$ da LBI alcunha no seu texto, caput, praticamente com todas as letras o Art. $1^{\circ}$ da CDPD, "diploma que conforme destacado acima [...] importa em inequívoca fonte de inspiração para o Estatuto" (FARIAS; CUNHA; PINTO, 2016, p. 22).

Necessário compreender a abrangência e dimensão desse grupo social no Brasil, representando uma parcela considerável, de acordo com os dados do Instituto Brasileiro de Geografia e Estatística - IBGE(Censo 2010) é de 45.606.048 milhões de pessoas com algum tipo de deficiência, o que representa o expressivo número de $23,9 \%$ da sociedade, onde $8,3 \%$ da população brasileira apresentava alguma deficiência severa, que estão distribuídas proporcionalmente entre as zonas rurais e urbanas e que as pessoas com mais idade teriam mais predisposição a se tornarem pessoas com deficiência, até pelo critério adquirido, desse modo, podemos ver mais dados abaixo:

Tabela 1 - Tipos de deficiência por gênero e faixa etária

\begin{tabular}{r|c|c|c|c|c|c}
\cline { 2 - 6 } & \multicolumn{7}{c}{ Tipo de Deficiência } \\
\cline { 2 - 7 } & $\begin{array}{c}\text { Ao menos } \\
\text { uma ou mais }\end{array}$ & Visual & Auditiva & Motora & $\begin{array}{c}\text { Mental ou } \\
\text { Intelectual }\end{array}$ & $\begin{array}{c}\text { Nenhuma } \\
\text { Deficiência }\end{array}$ \\
\hline Total & 23,9 & 18,8 & 5,1 & 7,0 & 1,4 & 76,1 \\
\hline Homens & 21,2 & 16,0 & 5,3 & 5,3 & 1,5 & 78,8 \\
\hline o a 14 & 7,3 & 4,8 & 1,4 & 1,0 & 1,0 & 92,7 \\
\hline 15 a 64 & 22,2 & 17,1 & 4,5 & 4,5 & 1,6 & 77,8 \\
\hline 65 ou mais & 64,5 & 47,3 & 28,2 & 30,9 & 2,8 & 35,4 \\
\hline Mulheres & 26,5 & 21,4 & 4,9 & 8,5 & 1,2 & 73,5 \\
\hline o a 14 & 7,8 & 5,9 & 1,3 & 1,0 & 0,7 & 92,2 \\
\hline 15 a 64 & 27,6 & 23,1 & 4,0 & 6,8 & 1,2 & 72,4 \\
\hline 65 ou mais & 70,1 & 51,7 & 23,6 & 44,0 & 3,0 & 29,9 \\
\hline
\end{tabular}

Quando se analisa por regiões, percebe-se que o Nordeste é a de maior incidência, com 26,63\% (maior ainda que a média brasileira) e o Estado da Bahia conta com 25,39\% na população, o que a torna menor que a do nordeste (somente perdendo para o Rio Grande do Norte, com 27,86\%), mas, ainda assim, acima da média nacional. No que diz respeito à raça, cor de pele ou etnia, temos que $23,4 \%$ se intitulam branca, $27,1 \%$ preta e $27,1 \%$ amarela, 23,8\% parda e por fim, 20,1\% indígena, nacionalmente, onde a intersecção de categorias pode também agravar vulnerabilizações, cruzando raça/etnia/cor, escolarização e sexo/gênero, por exemplo, que serão abordadas por este trabalho. 
Frisa-se que, em 2018, o IBGE ${ }^{11}$ fez uma releitura do presente dado, a partir de um parâmetro internacional ${ }^{12}$ supervenientemente criado, que exprime a deficiência por uma classificação de funcionalidade, fazendo com que os números de 2010(censo específico) de PcD's no Brasil tenham sido superdimensionados. Isso se deve ao fator de estudos comparados entre países, assinalando um indicativo de $23,9 \%$ que se autodeclaram, que anteriormente apontavam para o quantitativo de6,7\%. Tal novo enfoque parece mais apropriado e pertinente às definições internacionais atuais.

\section{Preceitos norteadores de cidadania, justiça e direitos humanos}

Para além da controvérsia populacional, constitucionalmente temos sido regidos, desde 1988, por uma carta magna tida como cidadã (expressão como foi denominada) e que o sistema de proteção internacional adentrou no ordenamento pátrio de tal modo que alargou o próprio contexto do termo Cidadania $^{13}$ como posto no cenário vindouro, onde o Brasil já pode experienciar decisões provenientes da próprio Corte Interamericana de Direitos Humanos da OEA, em outros eixos de discriminação.

Assim, denota-se que cidadão não é só aquele residente pátrio de uma nação, mas sim os que figurem como detentores e principalmente garantidores de direitos, onde, leia-se aqui, os de Direitos Fundamentais também (CUNHA JÚNIOR, 2015),que, de maneira complementar, preenchem pormenorizando no plano interno todo arcabouço internacional, que ora se utiliza do soft power ${ }^{14}$ para atingir tais garantias junto às nações. Impulsionada assim "agenda comum mundial, levando os Estados a estabelecerem projetos comuns, e, assim, poder superar as animosidades geradas" (RAMOS, 2002, p. 19), onde, muitas vezes, conseguiram, ao longo da história, acertadamente sobreposição pela norma-princípio do que pela norma regra (ALEXY, 2012).

Em qualquer lugar ou país, ser cidadão diz "respeito não só a uma determinada ordem jurídico-política de um país, de um Estado, no qual uma Constituição define e garante que é cidadão, que direitos e deveres ele terá"(SOARES, 2013, p. 3)propenso a uma série de

\footnotetext{
${ }^{11}$ Nota Técnica $n^{\circ}$ 01/2018 IBGE. Releitura dos dados de pessoas com deficiência no Censo Demográfico 2010, à luz das recomendações do Grupo de Washington. Disponível em https://bit.ly/3sRVZQO

${ }^{12}$ Washington Group. The Measurement of Disability Recommendations. Round of Censuses, 2011.

${ }^{13}$ BOBBIO, Norberto. A Era dos Direitos. Rio de Janeiro: Elsevier, 2014.

${ }^{14}$ NYE JR, Joseph S. Soft power: Os meios para o sucesso na política mundial. Assuntos públicos, 2004.
} 
variáveis como exemplo a deficiência. Sob esta ótica, os direitos sociais passam a exigir uma ingerência do Estado através de concretudes na ampliação de seus poderes e a necessidade de confirmar o estado desse estado de Bem-Estar Social - Welfare State ${ }^{15}$ (STRECK; MORAIS, 2014).

Ao tratar da inexequibilidade dos direitos fundamentais sociais, Bobbio reflete que não se trata da falta de fundamento no momento de sua positivação, mas sim a falta de ação, o que, atualmente pode-se entender que não é a necessidade "de justificá-los, mas o de protegê-los. Trata-se de um problema não filosófico, mas político" (2004, p.43). Nesse prisma, os direitos sociais não são mera manifestação de vontade do Poder Constituinte Originário ${ }^{16}$, de cunho programático, mas apresentam força normativa capaz de ensejar sua concretização por meio de políticas públicas, movimentos sociais ou pela reivindicação da tutela jurisdicional na garantia desses Direitos intrínsecos.

De modo que o transcurso geracional dos Direitos Humanos, tão bem sintetizados por Fonteles (2018) nos denota um sopro evolutivo gradual onde a educação, por meio da inclusão social e da promoção da justiça social se desenvolve nos mesmos moldes que a concepção de cidadania citada. Dessa forma, houve uma transposição de um modelo assistencialista e paternalista para uma universalização dos direitos ora humanos e transversais:

Quadro 1 - Conceito Geracional dos Direitos Humanos historicamente

\begin{tabular}{|l|l|l|l|l|}
\hline \multicolumn{1}{|c|}{$1^{\text {a Geração }}$} & \multicolumn{1}{|c|}{$2^{\text {a Geração }}$} & \multicolumn{1}{c|}{$3^{\text {a Geração }}$} & \multicolumn{1}{c|}{$4^{\text {a Geração }}$} & \multicolumn{2}{c|}{$5^{\text {a Geração }}$} \\
\hline $\begin{array}{l}\text { Final do } \\
\text { Século XVIII }\end{array}$ & $\begin{array}{l}\text { Início do } \\
\text { Século XX }\end{array}$ & $\begin{array}{l}\text { Final do } \\
\text { Século XX }\end{array}$ & Época Atual & $\begin{array}{l}\text { Época Atual (mais } \\
\text { recente) }\end{array}$ \\
\hline Estado Liberal & $\begin{array}{l}\text { Estado Social ou } \\
\text { Estado } \\
\text { Providência }\end{array}$ & $\begin{array}{l}\text { Estado } \\
\text { Democrático de } \\
\text { Direito }\end{array}$ & $\begin{array}{l}\text { Estado } \\
\text { Democrático de } \\
\text { Direito }\end{array}$ & $\begin{array}{l}\text { Estado } \\
\text { Democrático de } \\
\text { Direito }\end{array}$ \\
\hline Liberdade & Igualdade & Fraternidade & Globalização Política \\
\hline $\begin{array}{l}\text { Direitos Civis e } \\
\text { Políticos }\end{array}$ & $\begin{array}{l}\text { Direitos Sociais, } \\
\text { Econômicos e } \\
\text { Culturais }\end{array}$ & $\begin{array}{l}\text { Direitos Difusos, } \\
\text { Direito ao }\end{array}$ & $\begin{array}{l}\text { Democracia } \\
\text { Direta, } \\
\text { Informação e }\end{array}$ & $\begin{array}{l}\text { Paz } \\
\text { Universal }\end{array}$ \\
\hline
\end{tabular}

${ }^{15}$ ESPING-ANDERSEN, G. As três economias políticas do Welfare State. Lua Nova: Revista de Cultura e Política, n. 24, p. 85-116, 1991; KORNIS, George Edward Machado. A crise do Estado de Bem-Estar: problemas e perspectivas da proteção social. 1994 .

${ }^{16}$ BONAVIDES, Paulo. Curso de Direito Constitucional. 16a ed. São Paulo: Malheiros, 2005. 


\begin{tabular}{|l|l|l|l|l|}
\hline & & $\begin{array}{l}\text { Progresso } \\
\text { e à Paz }\end{array}$ & $\begin{array}{l}\text { Pluralismo } \\
\text { Patrimônio } \\
\text { Genético }\end{array}$ & \\
\hline Indivíduo & Grupo Social & Toda Humanidade \\
\hline
\end{tabular}

Fonte: (FONTELES, 2016).

Ciente de que é por meio da implementação de políticas públicas com vistas à materialização das normas programáticas esculpidas na positivação (inter)nacional que avistaremos o mais puro ideário de justiça, que é "dar a cada um o que é seu, na medida da sua desigualdade"17, ainda tão longínquo. Contudo, a a cidadania corresponde ao estado ativo dos direitos individuais, visto que se relacionam com a participação do indivíduo na tomada de decisões e direção da sociedade. Marshall (1967)refere-se à cidadania diante de três elementos: direitos civis, políticos e sociais e nesse último, as instituições mais intimamente ligadas são os serviços sociais e o sistema educacional.

Afirma, ainda, que o conceito tenha alargado, porque, inicialmente, a cidadania do indivíduo relacionava-se com o status que ele ocupava perante seus pares, assim, os direitos sociais não possuíam a concepção universalista como nos moldes atuais, onde não se acreditava que estes deveriam ser consolidados com a finalidade de reduzir as desigualdades sociais e promover a igualdade formal e material (LENZA, 2010). Então, atribui-se a Platão ${ }^{18}$ um dos primeiros tratamentos essenciais sobre a igualdade, "defendeu ele, na República, a igualdade de oportunidades [...]que se dessem chances às crianças virtuosas e talentosas para ultrapassarem as desigualdades sociais" (HELVESLEY, 2004, p. 1).

Ele ainda complementa que, na igualdade, se encontra o fundamento da própria democracia; para o filósofo, portanto, é uma característica de um Estado Democrático de Direito, diferentemente de como pensou Locke $(1994)^{19}$, onde a cidadania não se trata apenas da conquista de direitos, lidos estes através da lógica liberal pura e simples de propriedade, mas da sua materialização sob o enfoque da justiça social, o qual se coaduna através do princípio dignidade da pessoa humana(KUNTZ, 1998, p. 26).

Poderíamos até dizer que a eminência da dignidade da pessoa humana é tal que é dotada ao mesmo tempo da natureza de valor supremo, princípio

\footnotetext{
${ }^{17}$ ARISTÓTELES. Ética a Nicômaco. $4^{\mathrm{a}}$ ed. São Paulo: Martin Claret, 2008.

${ }^{18}$ PLATÃO. A República. São Paulo: Nova Cultural, 2000.

${ }^{19}$ LOCKE, John. Segundo Tratado sobre o Governo. Petrópolis: Vozes, 1994.
} 
constitucional fundamental e geral que inspiram a ordem jurídica. Mas a verdade é que a Constituição lhe dá mais do que isso... Portanto, não é apenas um princípio da ordem jurídica, mas o é também da ordem política, social, econômica e cultural. Daí sua natureza de valor supremo, porque está na base de toda a vida nacional (SILVA, 1998, p. 92).

Marcos legais (inter)nacionais de direitos humanos e inclusão da pessoa com deficiência

Nesse prisma, temos arraigado como fonte do Direito, desde o período da filosofia clássica, pautada no jusnaturalismo até o positivismo jurídico promovido por Kelsen, condensando esses ideais- na transição teleológica frente à norma positiva posta através da sociologia Comtiana. Assim, os historiadores prolatam que, para as dimensões dos Direitos Humanos já mencionadas, precisavam, em algum momento, ter consolidado uma agenda que pudesse focar em eixos temáticos, na construção desses marcos legais que visam fomentar o acesso à justiça e à cidadania.

Desde a Declaração Universal dos Direitos Humanos - DUDH (1948), temos consolidado uma agenda internacional, com atenção especializada para alguns eixos e construção (WOLKMER, 2002), do qual Piovesan (2004) preceitua a compreensão moderna dos direitos humanos, sendo esta de caráter universal e indivisível, trazida pela Declaração Universal de 1948, que apregoa a necessidade de realizar políticas públicas específicas para alcançar determinadas parcelas vulneráveis:

Universalidade porque clama pela extensão universal dos direitos humanos, sob a crença de que a condição de pessoa é o requisito único para a titularidade de direitos, considerando o ser humano como um ser essencialmente moral, dotado de unicidade existencial e dignidade, esta como valor intrínseco à condição humana. Indivisibilidade porque a garantia dos direitos civis e políticos é condição para a observância dos direitos sociais, econômicos e culturais e vice-versa. Quando um deles é violado, os demais também o são. Os direitos humanos compõem, assim, uma unidade indivisível, interdependente e inter-relacionada, capaz de conjugar o catálogo de direitos civis e políticos com o catálogo de direitos sociais, econômicos e culturais. (PIOVESAN, 2004, p. 88).

Podendo-se valer, não só do aparato de proteção no âmbito nacional inclusive, como, também, contam com a titularidade destes aos quais Ihe são oponíveis até mesmo no âmbito internacional, uma vez que o Brasil está sujeito a estes, condiciona a autora:

Em face dessa interação, o Brasil assume, perante a comunidade internacional, a obrigação de manter e desenvolver o Estado Democrático de Direito e de proteger, mesmo em situações de emergência, um núcleo de 
direitos básicos e inderrogáveis. Aceita ainda que essas obrigações sejam fiscalizadas e controladas pela comunidade internacional, mediante uma sistemática de monitoramento efetuada por órgãos de supervisão internacional.(PIOVESAN, 2013, p. 389).

Assim, toda essa agenda (inter)nacional pode aqui ser mencionada através de marcos positivados, ressaltando a transversalidade inerente aos Direitos Humanos, onde, para se ter educação, necessita-se de outros Direitos básicos e até mesmo universais:

Quadro 2 - Marcos legais de educação inclusiva (inter)nacionais (1948 - 2016)

\begin{tabular}{|c|c|c|}
\hline \multicolumn{3}{|r|}{ POLÍTICAS QUE FUNDAMENTARAM A INCLUSÃO } \\
\hline ANO & ORG. & LEGISLAÇÃO INTERNACIONAL \\
\hline 1948 & ONU & Declaração Universal dos Direitos Humanos \\
\hline 1975 & ONU & Declaração dos Direitos da Pessoa com Deficiência \\
\hline 1983 & OIT & Conferência Internacional do Trabalho \\
\hline 1990 & Unesco & Declaração Mundial sobre Educação para Todos \\
\hline 1993 & ONU & $\begin{array}{l}\text { Normas sobre a Equiparação de Oportunidades para Pessoas com } \\
\text { Deficiência }\end{array}$ \\
\hline 1993 & ONU & $\begin{array}{l}\text { Inclusão Plena e Positiva de Pessoas com Deficiência em Todos os Aspectos } \\
\text { da Sociedade }\end{array}$ \\
\hline 1994 & Unesco & $\begin{array}{l}\text { Declaração de Salamanca e Linhas de Ação sobre Educação para } \\
\text { Necessidades Especiais }\end{array}$ \\
\hline 1999 & ONU & Carta para o Terceiro Milênio \\
\hline 1999 & OEA & $\begin{array}{l}\text { Convenção da Guatemala - Convenção Interamericana para Eliminação de } \\
\text { Todas as Formas de Discriminação contra as Pessoas Portadoras de } \\
\text { Deficiência }\end{array}$ \\
\hline 2000 & - & Declaração de Manchester sobre Educação Inclusiva ${ }^{20}$ \\
\hline 2001 & OMS & $\begin{array}{lll}\text { Classificação Internacional de } & \text { Funcionalidade, } \\
\text { Deficiência e Saúde - CIF } & \\
\end{array}$ \\
\hline 2002 & - & Declaração Internacional de Montreal sobre Inclusão* \\
\hline 2003 & ONU & $\begin{array}{l}\text { Convenção Internacional para Proteção e Promoção dos Direitos e } \\
\text { Dignidade das Pessoas com Deficiência }\end{array}$ \\
\hline 2006 & ONU & Convenção Internacional sobre os Direitos das Pessoas com Deficiência \\
\hline 2015 & Unesco & Declaração de Incheon de Educação 2030 \\
\hline ANO & No & LEGISLAÇÃO NACIONAL BRASILEIRA \\
\hline 1988 & - & Constituição da República Federativa do Brasil. \\
\hline 1989 & 7.853 & $\begin{array}{l}\text { Apoio às Pessoas Portadoras de Deficiência - CORDE } \\
\text { (define crimes e outras providências) }\end{array}$ \\
\hline 1990 & 8.069 & Estatuto da Criança e do Adolescente - ECA \\
\hline 1990 & 8.112 & $\begin{array}{l}\text { Regime Jurídico dos servidores públicos civis da União - Reserva de cargos } \\
\text { nos concursos públicos, autarquias e fundações públicas federais }\end{array}$ \\
\hline 1994 & 8.859 & $\begin{array}{lccccc}\begin{array}{l}\text { Estende } \\
\text { o Direito à Participação em Estágio }\end{array} & & \text { de } & \text { Ensino } & \text { Especial } \\
\end{array}$ \\
\hline 1994 & 10.098 & $\begin{array}{llll}\text { Normas Gerais e } & \text { Critérios } & \text { Básicos } \\
\text { a Promoção da Acessibilidade } & & \\
\end{array}$ \\
\hline 1996 & $9 \cdot 394$ & Diretrizes e Bases da Educação Nacional \\
\hline
\end{tabular}

\footnotetext{
${ }^{20}$ Documentos de outros organismos mundiais não advindos da Organização das Nações Unidas (ONU).
} 


\begin{tabular}{|c|c|c|}
\hline 2000 & 10.048 & $\begin{array}{l}\text { Regulamenta a prioridade de atendimento às pessoas com deficiência ou } \\
\text { mobilidade reduzida }\end{array}$ \\
\hline 2000 & 10.098 & $\begin{array}{l}\text { Estabelece normas gerais e critérios básicos para a promoção da } \\
\text { acessibilidade das pessoas portadoras de deficiência ou com mobilidade } \\
\text { reduzida }\end{array}$ \\
\hline 2001 & 10.172 & Aprova o Plano Nacional de Educação (PNE) \\
\hline 2002 & 10.436 & Língua Brasileira de Sinais - LIBRAS \\
\hline 2004 & 10.845 & $\begin{array}{l}\text { Institui o Programa de Complementação ao Atendimento Educacional } \\
\text { Especializado às Pessoas Portadoras de Deficiência }\end{array}$ \\
\hline 2005 & 11.133 & Institui o Dia Nacional de Luta da Pessoa Portadora de Deficiência \\
\hline 2006 & - & Plano Nacional De Educação em Direitos Humanos \\
\hline 2007 & - & Plano de Desenvolvimento da Educação (PDE) \\
\hline 2008 & - & $\begin{array}{l}\text { Política Nacional de Educação Especial na Perspectiva da Educação } \\
\text { Inclusiva }\end{array}$ \\
\hline 2011 & 12.513 & $\begin{array}{l}\text { Institui o Programa Nacional de Acesso ao Ensino Técnico e Emprego } \\
\text { (Pronatec) }\end{array}$ \\
\hline 2014 & 13.005 & Plano Nacional de Educação - PNE \\
\hline 2015 & 13.146 & $\begin{array}{l}\text { Institui a Lei Brasileira de Inclusão da Pessoa com Deficiência (Estatuto da } \\
\text { Pessoa com Deficiência). }\end{array}$ \\
\hline ANO & No & DECRETOS DA UNIÃO FEDERATIVA DO BRASIL \\
\hline 1997 & 2.208 & $\begin{array}{l}\text { Regulamenta Lei } 9.394 \text { que estabelece as diretrizes e bases da educação } \\
\text { nacional. }\end{array}$ \\
\hline 1997 & 2.264 & Regulamenta a Lei n $9.424 / 96$ \\
\hline 1999 & 3.076 & Cria o CONADE. \\
\hline 1999 & 3.298 & Regulamenta a Lei n 7.853, de 24 de outubro de 1989 \\
\hline 2000 & 3.691 & Regulamenta a Lei n 8.899/96 \\
\hline 2001 & 3.952 & Conselho Nacional de Combate à Discriminação. \\
\hline 2001 & $3 \cdot 956$ & $\begin{array}{l}\text { (Convenção da Guatemala) Convenção Interamericana para a Eliminação } \\
\text { de Todas as Formas de Discriminação. }\end{array}$ \\
\hline 2004 & 5.296 & Regulamenta as Leis 10.048 e 10.098 - Acessibilidade. \\
\hline 2005 & 5.626 & Regulamenta a Lei 10.436 - LIBRAS. \\
\hline 2007 & 6.214 & Regulamenta o BPC às pessoas com deficiência. \\
\hline 2007 & 6.215 & Institui o Comitê Gestor de Políticas de Inclusão - CGPD \\
\hline 2008 & 6.571 & Dispões sobre o atendimento educacional especializado (AEE) \\
\hline 2009 & 6.949 & $\begin{array}{l}\text { Promulga a Convenção Internacional sobre os Direitos das Pessoas com } \\
\text { Deficiência e seu Protocolo Facultativo assinados em NY, } 2007\end{array}$ \\
\hline 2011 & 7.611 & $\begin{array}{l}\text { Revoga o DC 6.571/2008 e estabelece novas diretrizes para a Educação } \\
\text { Especial }\end{array}$ \\
\hline ANO & No & LEGISLAÇÃO DO ESTADO DA BAHIA \\
\hline 1989 & - & Constituição do Estado da Bahia \\
\hline 2002 & 8.268 & Cria o Conselho Estadual dos Direitos da Pessoa com Deficiência \\
\hline 2006 & 10.330 & Plano Estadual de Educação - PEE/BA (2006-2016) \\
\hline 2012 & 12.593 & $\begin{array}{l}\text { Define as funções e atribuições do Conselho Estadual dos Direitos da } \\
\text { Pessoa com Deficiência }\end{array}$ \\
\hline 2016 & 13.559 & Plano Estadual de Educação - PEE/BA (2016-2026) \\
\hline
\end{tabular}

Fonte: Elaboração dos autores. 
Desde a DUDH, então, é possível verificar no plano internacional a intenção de se declarar parâmetros mínimos para todas pessoas, assim exprimido em seu artigo $1^{0} ; 22$ e $26^{21}$ de nossa análise e a própria Constituição Federal de 1988-vigente, no seu artigo $5^{\circ}$ (Título II) Dos Direitos e Garantias Fundamentais e $6^{022}$ coloca a Educação como um Direito Social, exprimindo mais especificadamente sobre Educação Inclusiva em seu (Título III - Seção I) Da Educação, que bem disciplina essa garantia de direito em seus artigos 205; 206, I, 207; 208, III eV²3.Nesse sentido, assevera Duarte (2007), a atribuição estatal imbuída na Constituição tem o objetivo de corrigir as desigualdades sociais e, em última análise, alcançar a plena realização do princípio da dignidade da pessoa humana e o da justiça social como um todo.

Destacado o papel primordial das Convenções Internacionais, destaca-se a importância da UNESCO, com a Declaração Mundial sobre Educação para Todos (1990) e, principalmente, logo depois, a Declaração de Salamanca - e Linhas de Ação sobre Educação para Necessidades Especiais (1994), que proporcionou diálogo entre as Nações para, nos ordenamentos jurídicos internos dos países signatários, servirem como base para a implantação de políticas públicas de inclusão das pessoas com deficiência no sistema de ensino, conforme tabela correlacionada acima; diversas produções legislativas foram realizadas progressivamente no Brasil, com o objetivo de propiciar uma rede de ensino adequada, onde todo ambiente educacional deve ser para todos.

A partir disso, no plano interno/infraconstitucional, a Lei de Diretrizes e Bases da Educação Nacional -nº 9.394 (1996) disciplinou a educação escolar através do ensino em

\footnotetext{
${ }^{21}$ Art. $1^{0}$ - Todos os seres humanos nascem livres e iguais em dignidade e em direitos [...]; Art. 22 -Toda a pessoa, como membro da sociedade, tem direito à segurança social; e pode legitimamente exigir a satisfação dos direitos econômicos, sociais e culturais indispensáveis, graças ao esforço nacional e à cooperação internacional, de harmonia com a organização e os recursos de cada país; Art. 26 - Toda a pessoa tem direito à educação [...] o acesso aos estudos superiores deve estar aberto a todos em plena igualdade, em função do seu mérito. A educação deve visar à plena expansão da personalidade humana e ao reforço dos direitos do Homem e das liberdades fundamentais e deve favorecer a compreensão, a tolerância e a amizade [...] para a manutenção da paz.?

${ }^{22}$ Art. $5^{\circ}$ - Todos são iguais perante a lei, sem distinção de qualquer natureza [...]; Art. $6^{\circ}$ - São direitos sociais a educação, [...]. (Redação modificada pela Emenda Constitucional nº 9o, de 2015)

${ }^{23}$ Art. 205 - A educação, direito de todos e dever do Estado e da família, será promovida e incentivada com a colaboração da sociedade, visando ao pleno desenvolvimento da pessoa, seu preparo para o exercício da cidadania e sua qualificação para o trabalho; Art. 206 - O ensino será ministrado com base nos seguintes princípios: I - igualdade de condições para o acesso e permanência na escola [...]; Art. 207 - As universidades [...] obedecerão ao princípio de indissociabilidade entre ensino, pesquisa e extensão; Art. 208 - O dever do Estado com a educação será efetivado mediante a garantia de: III - atendimento educacional especializado aos portadores de deficiência, preferencialmente na rede regular de ensino; $V$ - acesso aos níveis mais elevados do ensino, da pesquisa e da criação artística, segundo a capacidade de cada um; [...]. (grifos nossos)
} 
todos os níveis (educação básica e superior), onde o ensino, então, deverá observar as qualidades do alunado, a criação de métodos específicos para as necessidades dos discentes, dentre outros, em igualdade de condições no Art. $3^{\circ}$, l; e já no Capítulo V - Da Educação Especial, no seu artigo 59 é assegurado recursos técnicos, prazo de conclusão adequado às necessidades, além de docentes especializados ${ }^{24}$.

De igual forma, o Decreto nº 3.298 de 1999 regulamentou a Lei nº 7.853 de 1989, dispondo sobre a Política Nacional para a Integração da Pessoa com Deficiência e determina a educação especial em todos os níveis de ensino, bem como pormenoriza os direitos e garantias do aluno especial, como, por exemplo, no Art. 27, pertinente aqui como horário adicional para realização de provas, nas ditas avaliações ${ }^{25}$.

A Resolução no 1 de 2002 do Conselho Nacional de Educação - CNE estabeleceu diretrizes para a formação do docente para atender às especificidades dos alunos com necessidades educacionais especiais, pelo AEE e, também em 2002, a Lei no 10.436 reconhece a Língua Brasileira de Sinais - LIBRAS como importante meio de comunicação e determina a difusão da mesma em todas as modalidades de ensino (Portaria no 2.678), bem como sua inclusão como disciplina curricular (Decreto $n^{\circ}$ 5.626) fazendo jus a toda comunidade surda ora excluída e não ocupante destes espaços emancipatório.

Ainda no âmbito nacional, destaca-se o Plano Nacional de Educação em Direitos Humanos (PNEDH) ${ }^{26}$ com três versões, a primeira em 2006 e a última versão encerrada em 2009 (PNEDH-3), tinha como objetivos traçar diretrizes e princípios com a finalidade de implantar a Educação em Direitos Humanos no país em todos os níveis de ensino, através de seus eixos aqui correlacionados. Em parceria com a UNESCO, o Estado e a Sociedade Civil organizada, de modo articulado e interfaceado com os atores políticos e sociais, formularam

24 Art. 59, III - professores com especialização adequada em nível médio ou superior, para atendimento especializado, bem como professores do ensino regular capacitados para a integração desses educandos nas classes comuns. (grifos nossos)

${ }^{25}$ Art. 27 - As instituições de ensino superior deverão oferecer adaptações de provas e os apoios necessários, previamente solicitados pelo aluno portador de deficiência, inclusive tempo adicional para realização das provas, conforme as características da deficiência.

${ }^{26}$ Art. 214, CFRB - A lei estabelecerá o plano nacional de educação, de duração decenal, com o objetivo de articular o sistema nacional de educação em regime de colaboração e definir diretrizes, objetivos, metas e estratégias de implementação para assegurar a manutenção e desenvolvimento do ensino em seus diversos níveis, etapas e modalidades por meio de ações integradas dos poderes públicos das diferentes esferas federativas. 
ações para estimular, na grade curricular, conteúdos relativos às pessoas com deficiência ainda na educação básica e, principalmente, propor políticas públicas que viabilizem a inclusão e a permanência da pessoa com deficiência na educação superior, criando uma cultura de direitos humanos, respeito às diversidades e construção da solidariedade pautadas pela cidadania e justiça social.

O PNEDH-3 possui 6 Eixos Orientadores, com o destaque para o Eixo III - Universalizar Direitos em um Contexto de Desigualdades, Diretriz 10 (Garantia da igualdade na diversidade) e Objetivo estratégico IV (Promoção e proteção dos direitos das pessoas com deficiência e garantia da acessibilidade igualitária), no qual destaca que o combate à discriminação cumulada com políticas compensatórias auxilia na igualdade a fim de que se promova a inclusão social ${ }^{27}$.

Assim, o Plano Nacional de Educação - PNE foi alterado a partir da Emenda Constitucional no 59 de 2009, possuindo, então, status constitucional, com prazo de alteração decenal, elaborado de forma articulada entre os Estados, Municípios e Distrito Federal, devendo possuir previsão orçamentária para sua execução.

Onde o PNE, para o decênio 2014-2024detém metas para redução das desigualdades e a valorização da diversidade ${ }^{28}$, já vale ressaltar que para 2024-2034 ainda não divulgado, mas já criticado, em razão de apresentação prévia da proposta governamental no documento "Compromisso Nacional pela Educação Básica", em julho de 2019, ante a ausência de qualquer menção à política inclusiva e do nosso objeto aqui estudado, sob o escopo do Ensino Superior.

Salientamos, por sua vez, a relevância da Lei Brasileira de Inclusão - LBI, de nº 13.146 de 2015, a qual reconhecemos no jargão jurídico como Estatuto da Pessoa com Deficiência EPD, entrelaçando todos esses pactos internacionais e agendas, como bem expresso em seu artigo $1^{0}$,congregando em dispositivo único todas essas garantias ${ }^{29}$ e, mais

\footnotetext{
27SECRETARIA DE DIREITOS HUMANOS. Programa Nacional de Direitos Humanos (PNEDH-3). 2010. Disponível em: http://www.dhnet.org.br/pndh/zuniversalizar/index.htm Acesso em 15 mai 2021.

${ }^{28}$ Meta 4 - Universalizar, para a população de 4 (quatro) a 17 (dezessete) anos com deficiência, transtornos globais do desenvolvimento e altas habilidades ou superdotação, o acesso à educação básica e ao atendimento educacional especializado, preferencialmente na rede regular de ensino, com a garantia de sistema educacional inclusivo, de salas de recursos multifuncionais, classes, escolas ou serviços especializados, públicos ou conveniados

29 Art. $1^{0}$ - É instituída a Lei Brasileira de Inclusão da Pessoa com Deficiência (Estatuto da Pessoa com Deficiência), destinada a assegurar e a promover, em condições de igualdade, o exercício dos direitos e das
} 
especificadamente em seu Capítulo IV - Do Direito à Educação30, prolatando em seu Art. 28 e 30 os deveres do poder público quanto ao desenvolvimento, implementação, acompanhamento e avaliação do sistema educacional inclusivo.

Por fim, adentrando na Constituição do Estado da Bahia (1989) vigente, em seu Capítulo XII - Da Educação, assegura o direito à Educação ${ }^{31}$ conforme residualmente auferida pela CF/88, e no Capítulo XXII - Do Deficiente, trata dos direitos da pessoa com deficiência32 e nitidamente ressalta a obrigatoriedade Estatal de cumprir tais deveres, onde, através do exposto, o artigo $250^{33}$ garante que por meio de lei será estabelecido o Plano Estadual de Educação da Bahia - PEE/BA, sendo concretizado pela Lei Estadual n 13.559 de 2016, para o decênio (2016-2026), aplicando-se as mesmas diretrizes referidas com destaque na educação inclusiva para a ampliação de políticas públicas e assistenciais nas Universidades Estaduais, onde já se tinha devidamente sido incorporada, mediante o Plano Estadual de Educação em Direitos Humanos - PEEDH, desde do ano de sua propositura(BAHIA, 2009).

Ainda nesse prisma, o Governo Estadual criou o documento intitulado Diretrizes da Educação Inclusiva no Estado da Bahia34, no qual apresentou um estudo com orientações aos profissionais da educação e definiu ações inclusivas para que os alunos com deficiência

liberdades fundamentais por pessoa com deficiência, visando à sua inclusão social e cidadania. Parágrafo único. Esta Lei tem como base a Convenção sobre os Direitos das Pessoas com Deficiência e seu Protocolo Facultativo, ratificados pelo Congresso Nacional [...].

$3^{30}$ Art. 27 - A educação constitui direito da pessoa com deficiência, assegurados sistema educacional inclusivo em todos os níveis e aprendizado ao longo de toda a vida, de forma a alcançar o máximo desenvolvimento possível de seus talentos e habilidades físicas, sensoriais, intelectuais e sociais, segundo suas características, interesses e necessidades de aprendizagem. Parágrafo único. É dever do Estado, da família, da comunidade escolar e da sociedade assegurar educação de qualidade à pessoa com deficiência, colocando-a a salvo de toda forma de violência, negligência e discriminação.

${ }^{31}$ Art. 247 - Lei disporá sobre o sistema estadual de ensino, tomando por base o dever do Estado com a educação, a ser efetivado mediante a garantia de: III - atendimento educacional especializado aos portadores de deficiência, preferencialmente na rede regular de ensino [...]; Art. 251 - A educação, para os portadores de deficiência física, mental ou sensorial, mediante o provimento de condições apropriadas, será efetivada em instituições específicas ou na rede regular, incluídos a estimulação precoce e o ensino profissional. (grifos nossos) ${ }^{32}$ Art. 285 - É dever do Estado assegurar às pessoas portadoras de qualquer deficiência a plena inserção na vida econômica e social e o total desenvolvimento de suas potencialidades, da seguinte forma: II - garantindo às pessoas portadoras de deficiência o direito à educação de primeiro e segundo graus e profissionalizante, obrigatória e gratuita, sem limite de idade. (grifos nossos)

${ }^{33}$ Art. 250 - Lei estabelecerá o Plano Estadual de Educação, de duração plurianual, proposto pelo Poder Executivo, com vistas à articulação e ao desenvolvimento do ensino em seus diversos níveis e à integração das ações do Poder Público, que conduzam aos objetivos previstos na Constituição Federal.

34 DA EDUCAÇÃO, Diretrizes. Secretaria da Educação do Estado da Bahia: Superintendência de Desenvolvimento da Educação Básica Diretoria de Ensino e duas Modalidades Coordenação de Educação Especial. Disponível em: http://www.educacao.ba.gov.br/system/files/private/midiateca /documentos/2017/diretrizesfinal.pdf Acesso em 15 mai 2021. 
ultrapassem as barreiras arquitetônicas e mercadológicas. Isso cria condições de aprendizagem em todos os níveis de ensino, onde se objetiva regras facilitadoras à acessibilidade, ao enriquecimento extracurricular e ao atendimento especializado da rede pública de ensino, mas podendo servir de fonte para o setor privado e para o próprio ensino superior, aqui por nós sempre referenciado.

\section{A pedagogia na educação inclusiva do ensino superior}

Diametralmente relevante é apontar o ideal de educação como utopia na concepção de um povo e suas características, onde a Universidade não pode se furtar a esse papel, dentro de um pressuposto da falta de autenticidade e adequação (RIBEIRO, 2011). Nessa ótica, é necessário compreender que, assim como os conceitos e ideais aqui apresentados mudaram ao longo do tempo, a própria educação necessitava desse acompanhamento, onde o mais inteligente e capaz nem sempre é o mais produtivo e as limitação não ditam necessariamente isto (GARDNER, 2009).

É preciso repensar a educação e sua ampliação para todos (UNESCO, 2007), reforçando a premência desse grupo ser objeto de políticas públicas educacionais "especiais", onde a acessibilidade é a principal propagadora de acesso e de maneira contemplativa podemos relacionar com o seguinte ensinamento:

Nesse sentido, proporcionar a acessibilidade espacial escolar visando a concretude dos direitos da PcD é fazer cumprir o papel da educação, que é o de empoderamento de pessoas na realização de outros estágios reivindicatórios, para além dos muros das escolas. (SILVA, 2019, p. 3)

Sendo recente na história das Universidades brasileiras, a democratização e a universalização do acesso ao ensino superior no país, isso devido às próprias questões de vulnerabilidade econômica, afinal, mundialmente $82 \%$ das PcD's vivem abaixo da linha da pobreza e há relação direta destas premissas (UNESCO, 2007). Compreende-se, assim, para além dos programas sociais que visam mitigar a barreira econômica elitista, ainda imposta ao nosso Ensino Superior, através de políticas afirmativas como Fundo de Financiamento Estudantil - Fies, o Programa Universidade para Todos - ProUni, as Cotas em IES Públicas35, onde todo esse movimento deve ser somado ao da própria inclusão, implicando uma

\footnotetext{
35 Políticas provenientes da última década propiciada pelo Governo Federal Brasileiro.
} 
ressignificação desses espaços e da maneira como o ensino perpassa, conforme preceito traduzido:

[...]a inteligência se constrói mediante a troca entre o organismo e o meio, mecanismo pelo qual se dá a formação das estruturas cognitivas. $O$ organismo com sua bagagem hereditária, em contato com o meio, perturba-se, desequilibra-se e, para superar esse desequilíbrio e se adaptar, constrói novos esquemas. (BRASIL, SEESP / SEED / MEC, 2007, p. 6).

Para além das barreiras arquitetônicas, "para ser integrado com êxito, espera-se que o aluno se adapte à escola, em vez de a escola se adaptar. Já a inclusão é um caminho a ser trilhado, mais do que um destino, um processo"(SILVA, 2019). Onde o educador tem papel fundamental nessa proposta e "a questão do sonho possível tem que ver com a educação libertadora enquanto prática utópica. Mas não utopia no sentido do irrealizável [...] "(FREIRE, 1982)esta é uma prática que vive unidade dialética, dinâmica, entre a denúncia e o anúncio, entre a oportunidade e a omissão.

Nesse diapasão, o processo de inclusão no Ensino Superior no Brasil perpassa desde a valorização das pessoas com deficiência, do reconhecimento de suas habilidades até pela diversificação na utilização dos recursos disponíveis, através de ações que busquem a construção do conhecimento dos discentes, respeitando a acessibilidade, as avaliações metodológicas e os materiais de estudos perante o papel do docente em enfrentar uma necessidade de fomento na tratada $\mathrm{AEE}^{36}$, com a finalidade precípua de atender para além dos discursos, mas sim a necessária realização de ações em concreto.

A inclusão é ir além do acesso aos serviços e suportes tecnológicos do aluno com deficiência, conforme preleciona Estevão, a educação baseada no princípio da inclusão "devia contribuir para a erradicação de todas as formas de discriminação, racismo e estereótipos ou incitamento ao ódio e a atitudes e preconceitos nocivos" (ESTEVÃO, 2015, p. 12). Com esse entendimento, o referido autor esclarece que a educação contribui para o desenvolvimento da cidadania, através da formação dos diálogos interculturais, assim, uma educação democrática não pode ser neutra, mas sim assumir a transformação de seus atores em autores e sujeitos detentores de Direitos, "cabendo à educação crítica, pela aprendizagem e

${ }^{36} \mathrm{AEE}$ : Atendimento Educacional Especializado, que organiza atividades, recursos pedagógicos e de acessibilidade, de forma complementar ou suplementar à escolarização dos estudantes com deficiência. 
pela prática de participação, um papel essencial na discussão democrática "(ESTEVÃO, 2006, p. 87).

A educação em si é um diálogo entre o discente e o docente no processo de ensinoaprendizagem, o qual se apresenta como um mecanismo de transformação e de reflexão sobre os Direitos Humanos. Nesse sentido, uma educação verdadeiramente emancipatória permite que os sujeitos se aproximem da realidade na qual estão inseridos. O patrono da educação, Paulo Freire, defende a existência de uma pedagogia além do ensino e aprendizagem, promovendo e ajudando o indivíduo a construir sua liberdade e ter a capacidade de exercê-la, de igual forma, havendo violações dos Direitos Humanos, é necessário denunciar a impunidade e se mobilizar criticamente:

A briga em favor dos Direitos humanos, onde quer que ela se trave. Do direito de ir e vir (liberdade ambulatorial), do direito de comer, de vestir, de dizer a palavra, de amar, de escolher, de estudar, de trabalhar. Do direito de crer e de não crer, do direito à segurança e à paz. (FREIRE, 2000).

Eficácia das políticas públicas existentes no Brasil

Nos últimos anos, as políticas públicas direcionadas para a inclusão das pessoas com deficiência no ensino superior sofreram diversas modificações, tendo o marco com a Lei no 9.394 de 1996, denominada Lei de Diretrizes e Bases da Educação Nacional - LDB, a qual alterou a forma de ingresso nas Universidades, entretanto, a aprovação dos diversos expedientes legais nas décadas passadas não foi suficiente e capaz de efetivar a permanência dos alunos com deficiência nas Instituições de Ensino Superior. Isso porque, embora tenha crescido o percentual de matrícula dos alunos com deficiência nas instituições de Ensino Superior a cada ano, o Censo da Educação Superior relativo a 2018, demonstra que apenas 0,52\% do total de alunos do país são pessoas com deficiência e com predominância na rede privada (BRASIL, 2018).

Diversas variáveis são analisadas sobre os reais motivos do não ingresso desses alunos nas IES brasileira, que vão desde a concorrência elevada, pautada na deslealdade meritocrática perquirida pelo ensino superior público, evidenciando as dificuldades de aprendizagem desse segmento no ensino formal massificado, não particularizado em suas especificidades durante toda vida escolar, ou até mesmo o elevado valor econômico agregado e intrinsicamente disposto para o ingresso na rede privada de Ensino Superior. 
Ainda assim, no comparativo do período de 2009 e 2017, houve um aumento de $86 \%$ de alunos com deficiência no Ensino Superior (BRASIL, 2017). Contudo, este número ainda é inexpressivo, quando comparado à totalidade de alunos regulares ingressantes no Ensino Superior. Com destaque aos dados realizados para com alunos PcD's inscritos na modalidade presencial de $0,44 \%$ e $0,48 \%$ de matrículas na modalidade de Ensino à Distância - EAD (CARDIAL, 2018), infelizmente, os dados versam acerca das matrículas, sem analisar as condições de permanência, desempenho e, principalmente, a participação do discente com deficiência no contexto de alteridade.

Já no tocante à Universidade Católica do Salvador-UCSal, ora estudada no presente artigo, o setor institucional para tratar acerca da inclusão é denominado PLENUS/CEAC e tem sua vinculação junto ao Núcleo de Assistência à Comunidade da Pró-Reitoria de Extensão e Ação Comunitária, que respondeu a esta pesquisa, afirmando ter registrado 30 inscritos entre os anos de 2016 a 2019, sendo destes 16 alunos com deficiência matriculados em 2019; 0 curso de Direito predomina entre as escolhas desse público discente, assim como em âmbito nacional (CARDIAL, 2018) e, novamente, quando comparada a relação desses acadêmicos para com o total de alunos presentes na Instituição, o percentual que se intitula pessoas com deficiência corresponde a apenas 1\%.

\section{Cartografia social: (3LS) integração, inserção e inclusão na ucsal}

Os três trazem, de forma didática, a temática, conforme figura a seguir, contemplam os conceitos que se subdividem em quatro aspectos necessariamente interligados:

Figura 1 - Compreendendo o que é inclusão

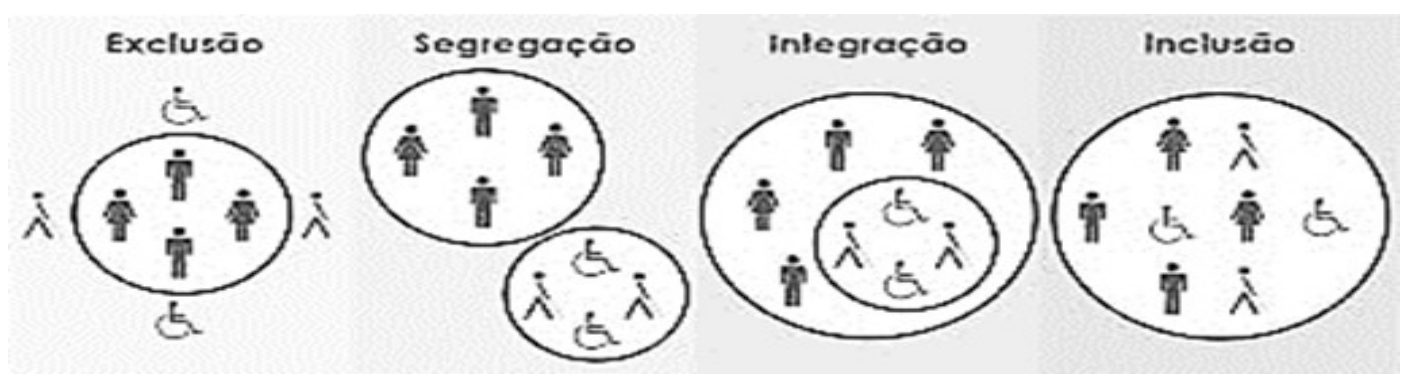

Fonte: Elaboração dos autores a partir de imagem do jornal Gazeta do Povo

É possível compreender o teor do chamado zls, quais sejam: Integração, no qual ele está no grupo, mas não de forma incluída, a Inserção que é algo mais puro e automático, sem 
respeito pela individualidade/características e, por fim, a tão sonhada Inclusão, frente à exclusão tão perene e visível na realidade empírica contrastada.

Partindo-se da coleta de dados, são apresentadas, na tabela abaixo, todas as perguntas que dizem respeito a questões socioeconômicas dos (do)discentes: 
Quadro 3-Perfil socioeconômico dos entrevistados

\begin{tabular}{|c|c|c|c|c|c|c|c|c|}
\hline & D1 & D2 & D3 & D4 & $\mathrm{D}_{5}$ & D6 & D7 & D8 \\
\hline TCLE $^{37}$ & Sim & Sim & Sim & Sim & Sim & Sim & Sim & Sim \\
\hline $\begin{array}{l}\text { Faixa } \\
\text { Etária }\end{array}$ & $25-64$ & $25-64$ & $25-64$ & $25-64$ & $25-64$ & $25-64$ & $25-64$ & Acima 65 \\
\hline Sexo / Gênero & Masculino & Masculino & Feminino & Masculino & Feminino & Masculino & Masculino & Masculino \\
\hline $\begin{array}{c}\text { Etnia / } \\
\text { Cor /Raça }\end{array}$ & Branco & Branco & Negra & Pardo & Parda & Branco & Branco & Branco \\
\hline $\begin{array}{l}\text { Considera } \\
\text { PcD? }\end{array}$ & Sim & Sim & Sim & Sim & Sim & $\operatorname{Sim}$ & Sim & Sim \\
\hline Classificação & Motora & Visual & Visual & Visual & Motora & Visual & Motora & Visual \\
\hline Limitação & Permanente & Permanente & Permanente & Permanente & Permanente & Permanente & Permanente & Adquirida \\
\hline Funcionário UCSal? & Não & Não & Não & Não & Sim & Não & Não & Não \\
\hline $\begin{array}{l}\text { Docente } \\
\text { UCSal? }\end{array}$ & Não & Não & Não & Não & Não & Não & Não & Sim \\
\hline Discente UCSal? & Sim & Sim & Sim & Sim & Sim & Sim & Sim & Não \\
\hline Nível/Vinculação & Pós-graduação & $\begin{array}{c}\text { Cursa } \\
\text { Pedagogia } \\
\end{array}$ & Cursa Direito & Cursa Direito & $\begin{array}{c}\text { Cursa } \\
\text { Fisioterapia }\end{array}$ & Pós-graduação & Pós-graduação & $\begin{array}{c}\text { Pós- } \\
\text { graduação }\end{array}$ \\
\hline Campus UCSal & Federação & Federação & Ambos & Ambos & Pituaçu & Federação & Federação & Ambos \\
\hline Período Ingresso & 2017.2 & 2016.2 & 2015.1 & 2016.2 & 2018.2 & 2019.1 & 2013.1 & ------ \\
\hline Apoio de Terceiro & Sim & Sim & Sim & Sim & Não & Sim & Não & Sim \\
\hline $\begin{array}{l}\text { Política Pública } \\
\text { Ingresso }\end{array}$ & Cotista & Trabalha & Beneficiário & Ambas & Trabalha & Cotista & Trabalha & Trabalha \\
\hline
\end{tabular}

Fonte: Elaboração dos autores a partir dos dados empíricos coletados.

37TCLE: Termo de Consentimento Livre e Esclarecido. 
É possível verificar, ultrapassados esses fatores socioeconômicos expostos, que os dois últimos se demonstram relevantes, pois ressalta a importância dos sujeitos invisibilizados: familiares e colaboradores (voluntários, remunerados in/diretamente) e a precariedade econômica sofrida por este grupo que necessita de políticas afirmativas para ingresso nas Instituições de Ensino Superior, tomando como base a própria UCSal.

Dentro das perguntas realizadas (seis ao total), obteve-se tais premissas: I - Se pensar em deficiência (a sua) e ambiente universitário, quais palavras podem ser evocadas? Temos os seguintes resultados, conforme Discente 1 "Dificuldades. Superação. Obstáculos" e a palavra "Acessibilidade" foi a que mais apareceu, três vezes. No item II - Ao longo de sua inserção no ensino superior como sentiu o ambiente acadêmico da UCSal? O Discente 3 respondeu "ponto positivo desafiador [...] negativo falta de acessibilidade"; já o Discente 4 afirma "receptivo, porém não há inclusão [...]".

No bojo da III - As experiências e a acessibilidade foram orientadas para formação integral como sujeito de Direitos e cidadania plena? O Discente 2 afirmou: "Sim, sobretudo quando tínhamos reuniões com o pró-reitor para discutir estratégias de melhorias para a situação da PcD no centro acadêmico", o que representava um apoio institucional específico e necessário. Na pergunta que segue, temos IV - Existe vivência de/na/para diversidade, especialmente com destaque às deficiências, incentivando educação ampliada e integração cidadã? Onde o Discente 6 diz "Não, a não ser do grupo do qual o pesquisador deste trabalho participa. Somos aceitos devido aos aportes da lei" demonstrando apenas cumprimento legal e não um querer comunitário ao acolhimento.

No próximo quesito, $\vee$ - Quais referências de inclusão e integração podem ser apontadas ao longo de seu processo no ensino superior? O primeiro entrevistado ressalta o seguinte "no sentido restrito, não apontaria nenhuma referência de inclusão, só de integração, sobretudo quando considerados determinados ambientes sem observância da adequada normatização de acessibilidade", demonstrando maior ênfase nas barreiras arquitetônicas ou metodológicas, inerentes a alguns tipos específicos de deficiência.

Por fim, indaga-se VI - Poderia sugerir/indicar situações de convivências e boas práticas em situações de real inclusão e integração? O Discente 2 firmemente responde "é importante que quando uma pessoa com deficiência adentre em um espaço acadêmico, ela se apresente mostrando suas virtudes e seus dificuldades, evitando ser o herói ou coitadinho. 
Não sendo o centro das atrações, todavia alguém que como os demais estar ali para conviver, integrar, aprender e ensinar", reafirmando o abordado.

\section{Considerações finais}

Diante de números e contextos relevantes, marcos legais e históricos levantados, evidencia-se a inércia do aparato estatal e da sociedade como um todo, onde jamais poderia continuar coexistindo em um ambiente intitulado pluralista; nesse diapasão, teve como principal influência, durante a primeira fase de estudos, o próprio materialismo histórico, afirmando que quem se beneficia da segregação é o próprio capitalismo, onde são os modelos sociais opressivos que levam as pessoas a experimentarem essa condição de "deficiência" (DINIZ, 2007, p. 23-24).

A partir disso, não quer dizer que a lesão não interessa ou, muito menos, o vulgarizar, pois tem-se o pertencimento, em contraposição ao darwinismo social de uma desvantagem atribuída naturalmente, de maneira absoluta e determinante, onde aqueles que trabalham eram lidos como principais, quando, na verdade, a justiça social é o preponderante para o público de pessoas com deficiência.

Em resposta a esta realidade e à absurda exoneração de responsabilidade estatal para com estas pessoas [...] constata-se o surgimento de visões contrárias, exigindo-se a responsabilidade da sociedade para com estas pessoas, mudando suas estruturas de forma a propiciar a inclusão.(VASCONCELLOS, 2019, p. 30).

Diante do problema de pesquisa proposto, chega-se à conclusão que inexiste inclusão plena no ambiente universitário da UCSal, prevalecendo a integração destes discentes, docentes e funcionários com deficiência, maneira esta qualitativa e empírica, demonstrando que todo arcabouço legal não é suficiente sem gestores comprometidos e políticas inclusivas continuadas, do contrário, somente restará uma acepção meramente formal, mesmo havendo acesso ao ensino, em nada poderá usá-lo na totalidade, vez que instituições críticas e éticas são difíceis atualmente.

\section{Referências}

ALEXY, Robert. Teoria dos Direitos Fundamentais. 2.ed. tradução Virgílio Afonso da Silva. São Paulo: Malheiros, 2012. 
BAHIA. Conselho Estadual de Educação. Resolução CEE nº 79, de 15 de setembro de 2009. Diário Oficial do Estado da Bahia. Salvador: 26 e 27 de set. 2009.

BAHIA. Comitê Estadual de Educação em Direitos Humanos. - Bahia: Secretaria da Justiça, Cidadania e Direitos Humanos. Plano do Estado da Bahia de Educação em Direitos Humanos, Salvador, 2009.

BAHIA. Secretaria da Educação. Coletânea Legislação Básica Educacional. Salvador: Superintendência de Organização e Atendimento da Rede Escolar/SEC.

BOBBIO, Noberto. A Era dos Direitos. Tradução: Carlos Nelson Coutinho. Rio de Janeiro: Elsevier, 2004.

BOBBIO. Norberto. A Teoria das Formas de Governo. Brasília: UnB, 2008.

BRASIL. Cartilha do Censo 2010: Pessoas com Deficiência. Brasília: SDH-PR/SNPD, 2012.

BRASIL. Comitê Nacional de Educação em Direitos Humanos. Plano Nacional de Educação em Direitos Humanos. Brasília: Secretaria Especial dos Direitos Humanos, Ministério da Educação, Ministério da Justiça, UNESCO, 2006.

BRASIL. Constituição (1988). Constituição da República Federativa do Brasil. Brasília, DF: Senado Federal: Centro Gráfico, 1988.

BRASIL. Convenção sobre os Direitos das Pessoas com Deficiência. Protocolo Facultativo à Convenção sobre os Direitos das Pessoas com Deficiência. Decreto Legislativo n 186/2008 Decreto no 6.949/2009. 4. ed. 4. rev. e atualizada. Brasília, 2012.

BRASIL. Declaração de Salamanca e linha de ação sobre necessidades educativas especiais. Brasília: UNESCO, 1994.

BRASIL. Diretrizes Operacionais para o Atendimento Educacional Especializado na Educação Básica - Modalidade Educação Especial. Resolução - No. 4 CNE/ CEB 2009.

BRASIL. Lei 13.146, de 06 de julho de 2015. Institui a Lei Brasileira de Inclusão da Pessoa com Deficiência. Brasília: Diário Oficial da República Federativa do Brasil, 2015.

BRASIL. Ministério Público Federal. $O$ acesso de alunos com deficiência às escolas e classes comuns da rede regular de ensino. Fundação Procurador Pedro Jorge de Melo e Silva (Orgs). Brasília: Procuradoria Federal dos Direitos do Cidadão, 2004.

BRASIL. Notas estatísticas do Censo Escolar 2017. Brasília, DF: INEP, 2017. Disponível em: http://portal.mec.gov.br/docman/setembro-2018-pdf/97041-apresentac-a-o-censo-superior-uItimo/file. Acesso em: 22 abr. 2020.

BRASIL. Notas estatísticas do Censo Escolar 2018. Brasília, DF: INEP, 2017. Disponível em: http://download.inep.gov.br/educacao_superior/censo_superior/documentos/2019/apresentacao_c enso_superior2018.pdf. Acesso em: 22 abr. 2020.

BRASIL. Política nacional de educação especial na perspectiva da educação inclusiva. Janeiro de 2008. Disponível: http://portaldoprofessor.mec.gov.br/storage/materiais/o000011730.pdf Acesso em 15 de nov. de 2020. 
BRASIL. SEESP / SEED / MEC (2007). Atendimento Educacional Especializado (AEE). Formação continuada à distância de professores para o atendimento educacional especializado. Deficiência Física. Disponivel em: http://portal.mec.gov.br/seesp/arquivos/pdf/aee_df.pdf. Acesso em: 10 mai. 2020.

CARDIAL, Edmílson. Matrículas de alunos com deficiência representam menos de 0,5\% do total. Revista do Ensino Superior, edição 225. 24 de janeiro de 2018. Disponível em: http://www.revistaensinosuperior.com.br/matriculas-de-alunos-com-deficienciarepresentammenos-de-05-do-total/. Acesso em: fevereiro de 2019.

CAVALCANTI, Vanessa Ribeiro Simon; SILVA, Antonio Carlos da. Entre mundos e discursos em prol dos Direitos Humanos: enlaces, agendas e redes ampliadas. In: BALLESTEROS, María De La Paz et. al. Pasado y presente de los Derechos Humanos: Mirando al futuro. Madrid: Catarata, 2016, pp. 447-459.

CAVALCANTI, Vanessa Ribeiro Simon; SILVA, Antonio Carlos da. Trilhas de uma história contemporânea: humanos direitos como agenda cada vez mais urgente. $4^{\circ}$ CONIDH: Direito Internacional dos Direitos Humanos, Democracia e Segurança, 2019, p. 12-26.

CHATEAU, Lilian et al. A associação da expressão necessidades especiais ao conceito de deficiência. Cadernos de Pós-Graduação em Distúrbios do Desenvolvimento, v. 12, n. 1, 2018.

CUNHA JÚNIOR, Dirley. Curso de Direito Constitucional. Salvador: JusPodivm, 2015.

D' Albuqueroue, T. R. L. O Estatuto da Pessoa com Deficiência e as Novas Perspectivas em torno da Mudança da Capacidade Civil. 2017. 117f. Dissertação (Mestrado) - Faculdade de Direito, Universidade Federal da Bahia, Salvador, 2017.

DE MARCO, Mario Alfredo. Do modelo biomédico ao modelo biopsicossocial: um projeto de educação permanente. Revista Brasileira de Educação Médica, v. 30, n. 1, p. 60-72, 2006.

STRAUB, Richard O. Psicologia da saúde: uma abordagem biopsicossocial. Porto Alegre: Artmed, 2014 .

DINIZ, Debora. O que é deficiência? São Paulo: Brasiliense, 2007. (Coleção Primeiros Passos; 324)

DUARTE, Clarice Seixas. A educação como um direito fundamental de natureza social. Educação e Sociedade, Campinas, vol.28, n. 100 - Especial, 691-713, out. 2007, p.692. Disponível em: https://www.scielo.br/pdf/es/v28n100/a0428100.pdf. Acesso em: 04 mai. 2020.

ESTEVÃO, Carlos Alberto Vilar. Direitos Humanos, Justiça e Educação: uma análise crítica das suas relações complexas em tempos Anormais. Ijuí: Unijuí, 2015.

ESTEVÃO, Carlos Alberto Vilar. Educação, justiça e direitos humanos. Educação e Pesquisa, 2006, vol.32, n.1, pp. 85-101.

FARIAS, Cristiano Chaves; CUNHA, Rogério; PINTO, Ronaldo. Estatuto da pessoa com deficiência comentado artigo por artigo - Conforme novo CPC. Salvador: JusPodivm, 2016.

FONTELES, S. S. Direitos Fundamentais. 2. ed. Salvador: Editora JusPodivm, 2016. 
FREIRE, Paulo. Educação: o sonho possível. In: BRANDÃO, Carlos R. (Org.). O Educador: vida e morte. Rio de Janeiro: Graal, 1982.

FREIRE, Paulo. Pedagogia da indignação: Cartas pedagógicas e outros escritos. São Paulo: Editora Unesp, 2000.

GARDNER, Howard; CHEN, Jie-Qi; MORAN, Seana. Inteligências múltiplas. São Paulo: Penso Editora, 2009.

GERHARDT, Tatiana Engel; SILVEIRA, Denise Tolfo (Orgs.). Métodos de pesquisa. Universidade Aberta do Brasil - UAB/UFRGS; Curso de Graduação Tecnológica - Planejamento e Gestão para o Desenvolvimento Rural da SEAD/UFRGS - (Coord.). Porto Alegre: Editora da UFRGS, 2009.

GOFFMAN, Ervig. Estigma: Notas sobre a manipulação da identidade deteriorada. Trad. Márcia Bandeira de Mello Leite Nunes. Rio de Janeiro: Copyright, 1988.

HÖFFE, Otfried. O que é justiça? Porto Alegre: Edipucrs, 2003.

HUNT, Lynn. A invenção dos direitos humanos: uma história. São Paulo: Companhia das Letras, 2009.

IBGE, Instituto Brasileiro de Geografia e Estatística. Censo Demográfico 2010. Características gerais da população, religião e pessoas com deficiência. Rio de Janeiro: IBGE, 2012.

KUNTZ, Rolf. Locke, liberdade, igualdade e propriedade. Clássicos do pensamento político, v. 2, p. 91-119, 1998.

KURZ, Robert. A Economia Política dos Direitos Humanos. Tradução de José Paulo Vaz, 08.11.2002 Disponivel em http://obeco.planetaclix.pt/rkurz110.htm Acesso em 16 de março de 2021.

KURZ, Robert. Os paradoxos dos Direitos Humanos: inclusão e exclusão na modernidade. Disponível em http://obeco.planetaclix.pt/rkurz116.htm Acesso em 16 de março de 2021.

LAZARI, Rafael de; GARCIA, Bruna. Manual de direitos humanos. Salvador: JusPodivm, 2017.

LENZA, Pedro. Direito constitucional esquematizado: igualdade formal e material. São Paulo: Saraiva, 2010.

LYRA FILHO, Roberto. O que é Direito. São Paulo: Brasiliense, 2003. (Coleção Primeiros Passos, 62).

MARQUES, Carlos Alberto. A estrutura paralela do ensino especial. Tribuna da Tarde, Juiz de Fora, 10 jul. 1992

MAROUES. Carlos Alberto. Implicações políticas da institucionalização da deficiência. Educação \& sociedade, v. 19, n. 62, p. 105-122, 1998.

MARSHALL, Thomas Humprey. Cidadania, classe social e status. Rio de Janeiro: Zahar, 1967.

ONU, Organização das Nações Unidas. 2006a. Convenção sobre os Direitos das Pessoas com Deficiência. Doc. A/61/611, Nova lorque, 13 dez. 
ONU, Organização das Nações Unidas. 2006b. Protocolo Facultativo à Convenção sobre os Direitos das Pessoas com Deficiência. Doc. A/61/611, Nova lorque, 13 dez.

ONU, Organização das Nações Unidas. Declaração Universal dos Direitos Humanos, de 10 de dezembro de 1948. Disponível em: http://unesdoc.unesco.org/imagens/0013/001394/139423por.pdf. Acesso em: 15 nov. 2020.

PIOVESAN, Flávia. Direitos humanos e o direito constitucional internacional. São Paulo: Saraiva, 2013.

PIOVESAN, Flávia. Proteção dos direitos sociais: desafios do ius commune sul-americano. Rev. TST, Brasilia, v. 77, n. 4, 2011, p. 105. Disponível em: https://juslaboris.tst.jus.br/bitstream/handle/20.500.12178/28340/004_piovesan.pdf Acesso em: 04 mai 2021.

PIOVESAN. Flávia. Temas de direitos humanos. São Paulo: Saraiva, 2017.

PUPPIN, Andrea. Da atualidade de Goffman para a análise de casos de interação social: deficientes, educação e estigma. Revista Brasileira de Estudos Pedagógicos, [S.I.], v. 80, n. 195, 1999.

RAMOS, André de Carvalho. Processo internacional de direitos humanos: análise dos sistemas de apuração de violações dos direitos humanos e a implementação das decisões no Brasil. Rio de Janeiro: Renovar, 2002.

RAUPP, Fabiano Maury; BEUREN, Ilse Maria. Ciências Sociais Aplicáveis às Ciências Sociais. In: BEUREN, Ilse Maria (Org.) Como Elaborar Trabalhos Monográficos em Contabilidade: Teoria e Prática. São Paulo: Atlas, 2013, p. 76-97.

RIBEIRO, Darcy. A universidade necessária. Em Aberto, v. 1, n. 10, 2011.

RIBEIRO, Djamila. Lugar de fala. São Paulo: Pólen, 2019.

ROMANOWSKI, Joana Paulin; ENS, Romilda Teodora. As pesquisas denominadas do tipo "estado da arte" em educação. Revista diálogo educacional, [S.I], v. 6, n. 19, p. 37-50, 2006.

SASSAKI, Romeu Kazumi. Terminologia sobre deficiência na era da inclusão. Mídia e deficiência. Brasília: Andi/Fundação Banco do Brasil, p. 160-165, 2003.

SILVA, José Afonso da. Curso de Direito Constitucional Positivo. São Paulo: Malheiros, 1998.

SOARES, Maria Victoria de Mesquita Benevides. Cidadania e direitos humanos. Cadernos de pesquisa, n. 104, p. 39-46, 2013.

SOARES, Ricardo Maurício Freire. O princípio constitucional da dignidade da pessoa humana. São Paulo: Saraiva, 2017.

STRECK, Lenio Luiz; MORAIS, José Luis Bolzan de. Ciência Política e Teoria Geral do Estado. 8.ed. rev. e ampl. Porto Alegre: Livraria do Advogado, 2014.

UNESCO, Organização das Nações Unidas para a Educação, a Ciência e a Cultura. Inclusão digital e social de pessoas com deficiência: textos de referência para monitores de telecentros. Brasília: 
UNESCO, 2007. Disponível em https://unesdoc.unesco.org/ark:/48223/pfooo0160012 Acesso em: 22 abr. 2020.

VASCONCELLOS, Milton Silva de. Uma cidade deficiente: o acesso às praias para pessoas com deficiência física em Salvador. 115f. Dissertação (Mestrado) - Programa de Pós-Graduação em Políticas Sociais e Cidadania, Universidade Católica do Salvador, Salvador, 2019.

WOLKMER, Antonio Carlos. Direitos Humanos: novas dimensões e novas fundamentações. Revista Direito em Debate, v. 11, n. 16-17, 2002.

WOLKMER, Antonio Carlos. Pluralismo jurídico, direitos humanos e interculturalidade. Sequência: Estudos Jurídicos e Políticos, v. 27, n. 53, p. 113-128, 2006.

\section{Detalhes dos autores}

\section{Antonio Carlos da Silva}

Doutor em Ciências Sociais pela Universidade de León. Professor do Programa de Pós-Graduação em Políticas Sociais e Cidadania da Universidade Católica do Salvador (PPGPSC/UCSAL) e coordenador do Núcleo de Estudos sobre Educação e Direitos Humanos (NEDH/UCSAL). Universidade Católica do Salvador. Salvador. Bahia. Brasil. E-mail: carlos.zamora@uol.com.br.

Matheus Martins de Oliveira

Mestrando em Políticas Sociais e Cidadania, Bacharel em Direito pela Universidade Católica do Salvador (UCSal), Bolsista de Iniciação Científica, financiado pela Fundação de Amparo à Pesquisa do Estado da Bahia (FAPESB). Integrante do Núcleo de Estudos sobre Direitos Humanos (NEDH/UCSal/CNPq).Salvador. Bahia. Brasil. E-mail: matheusm.oliveira@ucsal.edu.br. 